Mohamed Hassan MOURAD

Fish physiology

\title{
INFLUENCE OF BODY SIZE ON SWIMMING PERFORMANCE OF CARP (CYPRINUS CARPIO)
}

\section{WPL YW CIEZŻARU CIALA NA AKTYWNOŚĆ LOKOMOTORYCZNĄ U KARPIA (CYPRINUS CARPIO L.)}

\author{
Institute of Ichthyology, Department of Fish Physiology, Szczecin
}

The influence of body size on fish swimming performance was investigated. There was a positive correlation between body size and swimming speed. On the contrary, the relations between body size and time of fatigue, fish travel, physical effort were reverse. The reasons for the differences and the assumptions involved are discussed.

\section{INTRODUCTION}

Fish performance has been measured by many investigators, generally as a means for assessing fish condition. It is considered that swimming performance of fishes must be affected by several factors. Of the constraints on performance capacity, size is among the most important (Beamish, 1978). It is well known that the size of an aquatic organism can greatly influence metabolic activity, oxygen consumption, rate of energy expenditure, hydrodynamic drag and toxicity results (Brett, 1965; Schmidt-Nielsen, 1972; Williams and Brett, 1987; Mary et al. 1986; Degani et al. 1989).

The aim of the present work is to investigate the influence of body size upon the swimming performance of the carp under the applied load.

\section{MATERIALS AND METHODS}

Groups of carp (Cyprinus carpio), were brought to the laboratory and acclimated under the appropriate experimental conditions for one week. The fish were divided 
into 3 groups according to their weight; small (40-60 g); medium (60-80 g) and larg $(80-100 \mathrm{~g})$. Fish performance was obtained with the method of Wegrzynowicz and Kłyszejko (1972). According to this method, a float of a determined force buoyancy $(8 \%)$, was fixed to the dorsal. To overcome the buoyancy force of the float, the fish were constantly swimming. Four variables were recorded in this study in the following way:

1. Fish swimming speed by direct measurement of time required for the fish to swim over gauged distance.

2. Time of fatigue, i.e. swimming time until the signs of fatigue appeared: the fish were swimming up to the surface and remained there for some time without any motion.

3. Fish travel, as defined by the formula:

$$
S=\mathrm{VT}
$$

where: $S=$ fish travel $(\mathrm{m})$,

$\mathrm{V}=$ fish $\operatorname{speed}(\mathrm{m} / \mathrm{s})$,

$\mathrm{T}=$ swimming time (s).

4. Physical effort, as defined by the formula:

$$
\mathrm{L}=\mathrm{F}_{\mathrm{W}} \mathrm{S} \operatorname{ctg} \alpha
$$

where: $\mathrm{L}=$ physical effort $(\mathrm{Kg} \mathrm{m})$,

$\mathrm{F}_{\mathrm{w}}=$ buoyancy force of float $(\mathrm{Kg})$,

$S^{w}=$ fish travel $(\mathrm{m})$,

$\operatorname{ctg} \alpha=$ angle between the long axis of the fish and the water surface.

To evaluate the significance of changes caused by increase in body size, Student'st $t$ test was used.

\section{RESULTS AND DISCUSSION}

The effects of body size on swimming speed, time of fatigue, fish travel and physical effort are shown in Fig. 1(A-D). As shown in Fig. 1 (A), the mean swimming speed at body size of $40-60 \mathrm{~g}$ was $0.125 \mathrm{~m} / \mathrm{s}$. This mean increases to 0.127 and $0.132 \mathrm{~m} / \mathrm{s}$ in response to increase in the body size to $60-80$ and $80-100 \mathrm{~g}$, respectively. Statistically, these changes were found to be non-significant. These direct relationship between body size and swimming speed is normally due to the increase in fish volume and proportionate amount of muscle as well as the surface area of the gils. Also, body size is known to affect the white lateral muscle contraction time (Wardle, 1975; 1980). The results obtained are in agreement with (Brett, 1965; Fry and Cox, 1970; Joll, 1989; Wardle et al. 1989). 


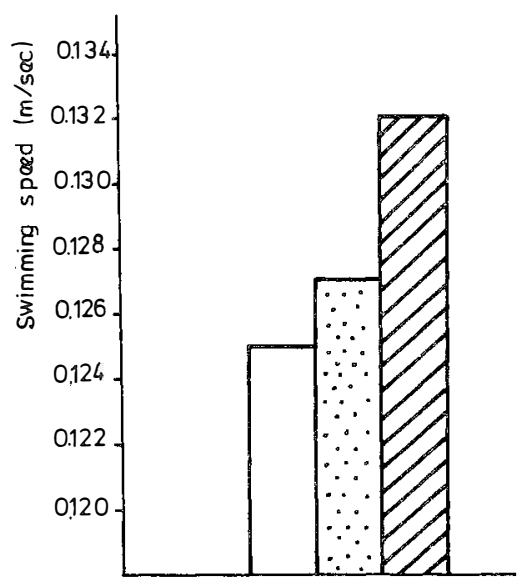

A

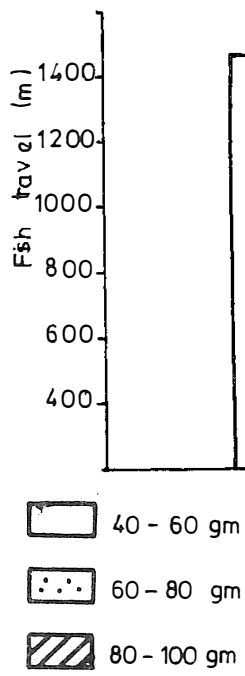

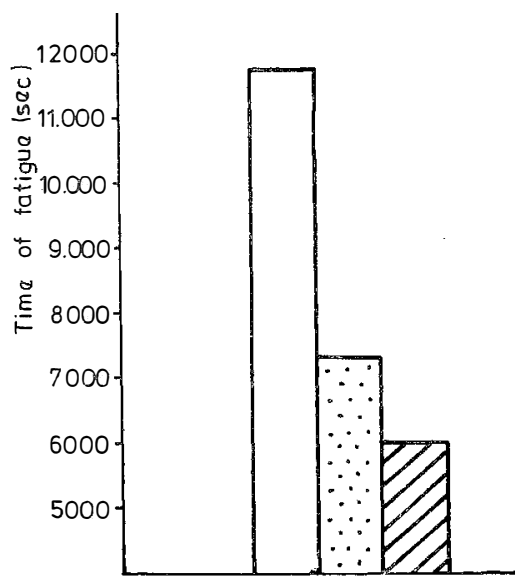

B

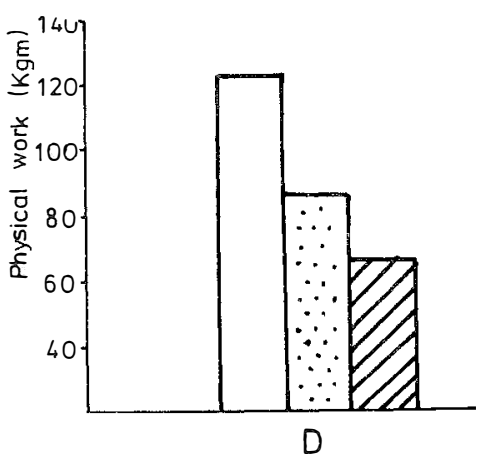

Fig. 1. Influence of body size on swimming performance: A. Swimming speed. B. Time of fatigue. C. Fish tavel. D. Physical effort

As sown in Fig. 1(B), there was a reverse relationship between the body size and time of fatigue, e.g. at $40-60 \mathrm{~g}$ body size, the time of fatigue was $11730 \mathrm{sec}$. This time was reduced to 7220 and $5960 \mathrm{~s}$. in response to an increase in the body size to 60-80 and $80-100 \mathrm{~g}$, respectively. Statistically, these changes were significant. It is known that muscular fatigue is produced by the accumulation of blood lactic acid which inflicts some physiological disturbances, e.g. decreases in $\mathrm{pH}$, heart rate and the affinity of haemoglobin to dissolved oxygen and carbon dioxide (Black, 1957; 1958; Redfield and Medearis, 1926). So we can suggest that the increase in time of fatigue that accompanied small fish may be related to enhanced efficiency of biochemical 
pathways or tolerance to the end product of anaerobic metabolism. Fig. 1(C), represents the effects of body size on fish travelling. It is evidenced that fish travelling decreased as body size increased. Statistically, these changes were significant. The results obtained are in accordance with Larimore and Duever (1968) who found that small fish may have relatively greater swimming ability than larger individuals.

As shown in Fig. 1(D), an increase in body size was found to be associated with a decrease in physical effort e.g. at 40-60 g, the physical effort was $120.780 \mathrm{Kg} / \mathrm{Kg}$. This effort decreased to 81.694 and $65.898 \mathrm{Kg} / \mathrm{Kg}$ in response to the body size increasing to $60-80$ and $80-100 \mathrm{~g}$, respectively. Statistically, these changes were significant. The increase in physical effort can be attributed to the observed increase in active metabolism in small fish (Brett, 1965), which suggests that some type of physiological changes may have occurred. Such an increase in active metabolic rate would agree with the contention of Fry (1974) that the swimming performance of a fish is closely related to its metabolic scope for activity. On the other hand, the reduced effort by larg fish may also be attributed to an increase in hydrodynamic drag which outweighed the advantage of increased body musculature (Brett, 1965), or to the increase in oxygen consumption, hence it is possible that large fish under loading condition may be unable to extract sufficient oxygen from the water for metabolic demand (Farmer and Beamish, 1969).

\section{CONCLUSIONS}

1. Body size of the carp significantly affects its swimming performance.

2. Swimming speed of the fish increases with size.

3. Time of fatigue, fish travel and physical effort of the carp decreases as the body size increases.

4. The method of apllsubjecting fish to physical effort proved useful in assessing the effects or body size.

\section{REFERENCES}

Beamish F.W.H., 1978: Swimming capacity. In: Fish Physiology (W.S. Hoar and D.J. Randall eds.), Academic Press, New York, 7: 101-172.

Black E.C., 1957: Alterations in the blood level of lactic acid in certain salmonid fishes following muscular activity. III. Sockeye salmon, Oncorhychus nerka. J. Fish. Res. Bd. Can., 14: 807-814.

Black E.C., 1958: Hyperactivity as a lethal factor in fish. Ibid., 15, 4: 573-586.

Brett J.R., 1965: The relation of size to rate of oxygen consumption and sustained swimming speed of sockeye salmon (Oncorhynchus nerka). J. Fish. Res. Bd. Can., 22, 6: 1491-1501.

Degani G., M. Gallagher and A. Meltzer, 1989: The influence of body size and temperature on oxygen consumption of European eel, Anguilla anguilla. J. Fish. Biol., 34: 19-24.

Farmer G.J. and F.W.H. Beamish, 1969: Oxygen consumption of Tilapia nilotica in relation to swimming speed and salinity. J. Fish. Res. Bd. Can., 26: 2807-2821. 
Fry F.E.J., 1947: Effects of environment on animal activity. Univ. Toronto Studies, Biol. Ser., No. 55, Publ. Ont. Fish. Res. Lab., No. 68: 62p.

Fry F.E.J. and E.T. Cox, 1970: A relation of size to swimming speed in rainbow trout. J. Fish. Res. Bd. Can., 27, 5: 976-978.

Joll L.M., 1989: Swimming behaviour of the saucer scallop Amusium ballot (Mollusco: Pectinidae). Marine Biol., 102: 299-305.

Larimore R.W. and M.J. Duever, 1968: Effects of temperature acclimation on the swimming ability of smallmouth bass fry. Trans. Am. Fish. Soc., 97: 175-184. .

Mary A., R. Sarojini and R. Nagabhushanam, 1986: Size and sex related tolerance to organochloride pesticides in freshwater prawn, Macrobrachium lamerrii. Indian J. Comp. Anim. Physiol., 4, 1: 29-34.

Redfield A.C. and D.N. Medearis, 1926: The content of lactic acid and the development of tension in cardiac muscle. Am. J. Physiol., 77: 662-668.

Schmidt-Nielsen K., 1972: Locomotion: Energy cost of swimming, flying and running. Science, 177, $222-228$.

Wardle C.S., 1975: Limit of fish swimming speed. Nature, London, 255: 727-757.

Wardle C.S., 1980: Effect of temperature on the maximum swimming speed of fish. In: The Environmental Physiology of Fishes (M.A.Al., ed.), New York, Plenum: 519-531.

Wardle C.S., J. Videler, T. Arimoto, J. Franco and P. He, 1989: The muscle twitch and the maximum swimming speed of giant bluefin tuna, Thunnus thynnus L. J. Fish. Biol., 35: 129-137.

Wegrzynowicz R. and B. Ktyszejko, 1972: Method for application of physical effort to fish. Acta Ichthyologica et Piscatoria, 2, 1: 91-94.

Williams I.V. and J.R. Brett, 1987: Critical swimming speed of Faster and Thompson River pink salmon (Oncorhynchus gorbuscha). Can. J. Aquat. Sci., 44: 348-356.

Mohamed Hassan MOURAD

\section{WPEYW CIĘŻARU CIA£A NA AKTYWNOŚĆ LOKOMOTORYCZNĄ U KARPIA (CYPRINUS CARPIO L.)}

\section{STRESZCZENIE}

Przeprowadzono badania zdolności do aktywnego wysiłku fizycznego karpia, w zależności od ciężaru ciała.

W wyniku badań stwierdzono, że ciężar ciała istotnie wpływa na zdolnošć ryb do aktywnego wysiłku. Szybkošć pływania zwiększała się wraz ze wzrostem ciężaru ciała ryb, natomiast czas zmęczenia, droga przebyta przez rybę oráz wysiłek fizyczny zmniejszały się.

Author's address:

Received: 1990.11.13

Dr Mohamed Hassan Mourad

Institute of Oceanography and Fisheries

Alexandria, Egipt 